\title{
Lack of association of vitamin $D$ receptor gene polymorphisms with susceptibility to type 1 diabetes mellitus in the Portuguese population
}

\author{
Manuel C. Lemos ${ }^{a, b, c, *}$, Ana Fagulha ${ }^{b}$, Eduarda Coutinhoc, Leonor Gomes ${ }^{b}$, \\ Margarida Bastos $^{\mathrm{b}}$, Luisa Barros ${ }^{\mathrm{b}}$, Francisco Carrilho ${ }^{\mathrm{b}}$, Elizabete Geraldes ${ }^{\mathrm{b}}$, \\ Fernando J. Regateiroc, Manuela Carvalheiro ${ }^{b}$
}

\author{
a Health Sciences Research Centre (CICS), Faculty of Health Sciences, University of Beira Interior, 6200-506 Covilhã, \\ Portugal \\ b Endocrinology, Diabetes, and Metabolism Service, University Hospital of Coimbra, 3000-075 Coimbra, Portugal \\ c Medical Genetics Service, Faculty of Medicine, University of Coimbra, 3004-504 Coimbra, Portugal
}

Received 15 November 2007; received in revised form 17 January 2008; accepted 23 January 2008

\author{
KEYWORDS \\ Vitamin D receptor; \\ VDR; \\ Single nucleotide \\ polymorphism; \\ SNP; \\ Type 1 diabetes \\ mellitus; \\ Genetic susceptibility
}

\begin{abstract}
Summary The vitamin $D$ receptor $(V D R)$ gene is a candidate gene for susceptibility to autoimmune disorders. Association studies of VDR polymorphisms and risk of type 1 diabetes often produced conflicting results in different ethnic backgrounds. The aim of this study was to test for association between common VDR polymorphisms and the genetic susceptibility to type 1 diabetes in the Portuguese population. We genotyped 207 patients with type 1 diabetes and 249 controls for the Fokl T>C (rs10735810), Bsml A $>$ G (rs1544410), Apal G>T (rs7975232), and Taql C > T (rs731236) single nucleotide polymorphisms by polymerase chain reaction and restriction fragment length polymorphism analysis. The distribution of VDR genotype, allele, and haplotype frequencies did not differ significantly between patients and controls. These data suggest that the single nucleotide polymorphisms of the VDR gene are unlikely to contribute significantly to type 1 diabetes susceptibility in the Portuguese population.

(c) 2008 American Society for Histocompatibility and Immunogenetics. Published by Elsevier Inc. All rights reserved.
\end{abstract}

\section{Introduction}

Vitamin $D$ is a potent modulator of the immune system and is involved in the regulation of cell proliferation and differentiation [1]. Vitamin D is an effective immunosup-

${ }^{*}$ Corresponding author. Fax. +351 275329099.

E-mail address: mclemos@fcsaude.ubi.pt (M.C. Lemos). pressant via inhibition of lymphocyte activation and cytokine production [1] and prevents or markedly suppresses the development of several autoimmune diseases in animal models [1]. The administration of vitamin $D$ protects against the development of insulitis and type 1 diabetes in nonobese diabetic mice [2]. In humans, epidemiological studies indicated that dietary vitamin D supplementation during early childhood decreases the risk of type 1 diabe- 


\section{ABBREVIATIONS}

BP base pairs

PCR polymerase chain reaction

SNP single nucleotide polymorphism

VDR vitamin D receptor

tes $[3,4]$ and that maternal intake of vitamin $D$ during pregnancy may have a protective effect on the appearance of islet autoantibodies in offspring [5].

Because vitamin D exerts its effects through the vitamin D receptor (VDR), the VDR gene has become a candidate susceptibility gene for type 1 diabetes. The VDR gene is located on chromosome 12q12-q14 and includes eight protein-coding exons (exons 2-9) and six untranslated exons (exons 1a-1f), which are alternatively spliced [6]. Four common single nucleotide polymorphisms (SNPs) in the VDR gene have been investigated extensively: Fokl T $>C$ (rs10735810), Bsml A > G (rs1544410), Apal G > T (rs7975232), and Taql C > T (rs731236). Allele T of the Fokl SNP creates an alternative ATG initiation codon in exon 2 leading to a VDR protein that is three amino acids longer [7]. The Bsml and Apal SNPs are both located in intron 8 , and the Taql is a silent SNP in exon 9. The four SNPs were tested for association with various human diseases [8] and affected the risk of endocrine immune-mediated disorders such as Graves' disease, Hashimoto's thyroiditis and Addison's disease [8-10]. Several studies also reported the association of type 1 diabetes with one or more of the four SNPs. However, the reported associations are inconsistent among studies [11].

The aim of this study was to assess the contribution of these VDR polymorphisms to the susceptibility to type 1 diabetes in the Portuguese population.

\section{Subjects and methods}

\section{Subjects}

The study group consisted of 207 Caucasian Portuguese patients with type 1 diabetes mellitus ( 113 males and 94 females; mean age at time of study \pm SD $=27.5 \pm 10.2$ years) who attended the outpatient clinics at the University Hospital of Coimbra (Portugal). Diabetes was diagnosed according to World Health Organization criteria [12] and classified as type 1 on the basis of classical clinical presentation [12], low or undetectable levels of serum C-peptide, and the presence of one or more autoantibodies (islet cell autoantibodies, autoantibodies to insulin, autoantibodies to glutamic acid decarboxylase (GAD65), or autoantibodies to the tyrosine phosphatase IA-2). Mean duration of diabetes was $11.4 \pm 8.3$ years (mean \pm SD). The control group consisted of 249 unrelated volunteers (143 males and 106 females; mean age \pm SD $=36.8 \pm 13.8$ years) who were blood donors and hospital and faculty staff with no history of autoimmune or other chronic diseases from the same geographical region. Portugal has approximately 10 million inhabitants and the annual incidence rate for type 1 diabetes was estimated at about 10 per 100,000 [13]. Informed consent was obtained from patients and controls.

\section{Genotyping}

Genomic DNA was extracted from whole blood using standard protocols. DNA was amplified by polymerase chain reaction (PCR) using previously described primer sequences [14]. Amplified fragments were digested with the appropriate restriction enzyme (New England Biolabs, Beverly, MA, USA) according to the manufacturer's instructions and visualized on a $3 \%$ agarose gel. The Fokl T $>C$ (rs10735810) SNP was analyzed by digestion of a 267-base pair (bp) PCR product with Fokl, which resulted in two fragments of 206 and $61 \mathrm{bp}$ in the presence of the T allele and in an uncut fragment in the presence of the $C$ allele. The $B s m l A>G$ ( $r$ 1544410) SNP was analyzed by digestion of a 191-bp PCR product with Bsml, which resulted in two fragments of 115 and $76 \mathrm{bp}$ in the presence of the $G$ allele and in an uncut fragment in the presence of the $A$ allele. The Apal G > T (rs7975232) and Taql C > T (rs731236) SNPs were analyzed by digestion of a 745-bp PCR product with Apal, which resulted in two fragments of 528 and $217 \mathrm{bp}$ in the presence of the $\mathrm{G}$ allele and in an uncut fragment in the presence of the T allele, and by digestion with Taql, which resulted in three fragments of 293, 251, and $201 \mathrm{bp}$ in the presence of the $\mathrm{C}$ allele and in two fragments of 494 and $251 \mathrm{bp}$ in the presence of the T allele. VDR haplotypes derived from Fokl, Bsml, Apal, and Taql polymorphisms were constructed using informative combinations of genotypes (e.g., an individual genotyped as CT/AA/GG/TT was considered to possess haplotypes $\mathrm{C} / \mathrm{A} / \mathrm{G} / \mathrm{T}+\mathrm{T} / \mathrm{A} / \mathrm{G} / \mathrm{T})$. Individuals heterozygous for more than one polymorphic site were not considered for haplotype frequency analysis, because the distribution of the alleles between the two homologous chromosomes could not be unequivocally defined (e.g., an individual genotyped as $\mathrm{CT} / \mathrm{AG} / \mathrm{GG} / \mathrm{TT}$ could possess either haplotypes $\mathrm{C} / \mathrm{A} / \mathrm{G} / \mathrm{T}+\mathrm{T} / \mathrm{G} / \mathrm{G} / \mathrm{T}$ or $\mathrm{C} / \mathrm{G} / \mathrm{G} / \mathrm{T}+\mathrm{T} / \mathrm{A} / \mathrm{G} / \mathrm{T}$ ).

\section{Statistical analysis}

Pearson's $\chi^{2}$ test of independence, with one degree of freedom, was used to examine differences of genotype, allele, and haplotype frequencies between patients and controls. When expected values were less than 5, Fisher's exact test was used. Two-tailed $p$ values were calculated and statistical significance was set at $p<0.05$. Odds ratios and the corresponding $95 \%$ confidence intervals were calculated for each genotype, allele, and haplotype. HardyWeinberg equilibriums were assessed using the $\chi^{2}$ goodness of fit test to compare the observed and allele-based expected genotype frequencies. Power calculation was analyzed using the program Power and Sample Size Calculations (Version 2.1.30).

\section{Results}

All frequencies were in Hardy-Weinberg equilibrium. The distribution of VDR genotype and allele frequencies did not differ significantly between patients with type 1 diabetes mellitus and controls (Table 1). No single genotype or allele was associated with an altered risk for type 1 diabetes mellitus. Because there were three possible genotypes for each of the four SNPs, each individual was classified as having one of the 81 possible combinations of genotypes. The distribution of these genotype combinations did not differ between patients and controls (data not shown). VDR haplotypes could be deduced from informative combinations of genotypes in 44.9 and $44.8 \%$ of patient and control haplotypes, respectively. VDR haplotype frequencies did not differ significantly between patients and controls (Table 2). Power analysis demonstrated that the study sample size was sufficient to detect odds ratios of 1.45 to 1.49 for each studied 
Table 1 VDR genotype and allele frequencies in patients with type 1 diabetes mellitus and controls.

\begin{tabular}{|c|c|c|c|c|}
\hline Polymorphism & Controls, $n(\%)$ & Patients, $n(\%)$ & Odds ratio $(95 \% \mathrm{Cl})$ & $p$ value \\
\hline Fokl genotype & $n=249$ & $n=207$ & & \\
\hline $\mathrm{CC}$ & 97 (38.9) & 81 (39.1) & $1.01(0.69-1.47)$ & 0.970 \\
\hline $\mathrm{CT}$ & 114 (45.8) & $101(48.8)$ & $1.13(0.78-1.63)$ & 0.522 \\
\hline $\mathrm{TT}$ & $38(15.3)$ & $25(12.1)$ & $0.76(0.45-1.31)$ & 0.327 \\
\hline \multicolumn{5}{|l|}{ Fokl allele } \\
\hline C & $308(61.8)$ & $263(63.5)$ & $1.07(0.82-1.41)$ & 0.602 \\
\hline $\mathrm{T}$ & $190(38.2)$ & $151(36.5)$ & $0.93(0.71-1.22)$ & 0.602 \\
\hline Bsml genotype & $n=248$ & $n=207$ & & \\
\hline AA & $56(22.6)$ & $43(20.8)$ & $0.90(0.58-1.41)$ & 0.642 \\
\hline AG & $107(43.1)$ & $96(46.4)$ & $1.14(0.79-1.65)$ & 0.490 \\
\hline GG & $85(34.3)$ & $68(32.8)$ & $0.94(0.64-1.39)$ & 0.749 \\
\hline \multicolumn{5}{|l|}{ Bsml allele } \\
\hline$A$ & $219(44.2)$ & $182(44.0)$ & $0.99(0.76-1.29)$ & 0.954 \\
\hline G & $277(55.8)$ & $232(56.0)$ & $1.01(0.78-1.31)$ & 0.954 \\
\hline Apal genotype & $n=232$ & $n=205$ & & \\
\hline GG & $63(27.2)$ & $50(24.4)$ & $0.87(0.56-1.33)$ & 0.510 \\
\hline GT & $101(43.5)$ & $100(48.8)$ & $1.24(0.85-1.80)$ & 0.272 \\
\hline $\mathrm{TT}$ & $68(29.3)$ & $55(26.8)$ & $0.88(0.58-1.34)$ & 0.565 \\
\hline \multicolumn{5}{|l|}{ Apal allele } \\
\hline G & 227 (48.9) & $200(48.8)$ & $0.99(0.76-1.30)$ & 0.967 \\
\hline $\mathrm{T}$ & $237(51.1)$ & $210(51.2)$ & $1.01(0.77-1.31)$ & 0.967 \\
\hline Taql genotype & $n=232$ & $n=205$ & & \\
\hline $\mathrm{CC}$ & $46(19.8)$ & $41(20.0)$ & $1.01(0.63-1.61)$ & 0.964 \\
\hline $\mathrm{CT}$ & $95(41.0)$ & $94(45.9)$ & $1.22(0.84-1.78)$ & 0.302 \\
\hline $\mathrm{TT}$ & 91 (39.2) & $70(34.1)$ & $0.80(0.54-1.19)$ & 0.272 \\
\hline \multicolumn{5}{|l|}{ Taql allele } \\
\hline C & $187(40.3)$ & $176(42.9)$ & $1.11(0.85-1.46)$ & 0.432 \\
\hline $\mathrm{T}$ & 277 (59.7) & $234(57.1)$ & $0.90(0.69-1.18)$ & 0.432 \\
\hline
\end{tabular}

$n=$ number; $\mathrm{Cl}=$ confidence interval.

allele, with an estimated power of 0.8 and a type 1 error probability of 0.05 .

\section{Discussion}

The VDR locus has been studied in different populations for association with susceptibility to immune-mediated dis- eases, but with inconsistent findings in type 1 diabetes mellitus [11]. To clarify the contribution of VDR polymorphisms to genetic susceptibility to type 1 diabetes mellitus among Portuguese patients, we conducted a retrospective casecontrol study by analyzing four well-characterized VDR polymorphisms. We reported no evidence of allelic or genotypic association of the Fokl T $>C$ (rs10735810), Bsml $A>G$

Table 2 VDR haplotype frequencies in patients with type 1 diabetes mellitus and controls.

\begin{tabular}{|c|c|c|c|c|}
\hline Haplotype ${ }^{a}$ & Controls, $n(\%)$ & Patients, $n$ (\%) & Odds ratio $(95 \% \mathrm{Cl})$ & $p$ value \\
\hline Fokl/Bsml/Apal/Taql & $n=223$ & $n=186$ & & \\
\hline $\mathrm{C} / \mathrm{G} / \mathrm{G} / \mathrm{T}$ & $77(34.5)$ & $66(35.5)$ & $1.04(0.69-1.57)$ & 0.840 \\
\hline $\mathrm{C} / \mathrm{A} / \mathrm{T} / \mathrm{C}$ & $56(25.1)$ & $52(28.0)$ & $1.16(0.75-1.80)$ & 0.516 \\
\hline $\mathrm{T} / \mathrm{G} / \mathrm{G} / \mathrm{T}$ & $50(22.4)$ & $35(18.8)$ & $0.80(0.50-1.30)$ & 0.371 \\
\hline $\mathrm{T} / \mathrm{A} / \mathrm{T} / \mathrm{C}$ & $16(7.2)$ & $10(5.4)$ & $0.74(0.33-1.63)$ & 0.458 \\
\hline $\mathrm{C} / \mathrm{G} / \mathrm{T} / \mathrm{T}$ & $11(4.9)$ & $13(7.0)$ & $1.45(0.65-3.25)$ & 0.378 \\
\hline $\mathrm{T} / \mathrm{G} / \mathrm{T} / \mathrm{T}$ & $5(2.2)$ & $4(2.2)$ & $0.96(0.27-3.35)$ & 1.000 \\
\hline $\mathrm{C} / \mathrm{A} / \mathrm{T} / \mathrm{T}$ & $4(1.8)$ & $1(0.5)$ & 0.30 (0.04-1.99) & 0.382 \\
\hline $\mathrm{C} / \mathrm{A} / \mathrm{G} / \mathrm{T}$ & $3(1.3)$ & $2(1.1)$ & $0.80(0.16-4.04)$ & 1.000 \\
\hline $\mathrm{T} / \mathrm{A} / \mathrm{G} / \mathrm{T}$ & $1(0.4)$ & 0 & $0.00(0.00-4.61)$ & 1.000 \\
\hline $\mathrm{C} / \mathrm{A} / \mathrm{G} / \mathrm{C}$ & 0 & $2(1.1)$ & $\infty(0.63-\infty)$ & 0.206 \\
\hline $\mathrm{T} / \mathrm{A} / \mathrm{G} / \mathrm{C}$ & 0 & $1(0.5)$ & $\infty(0.31-\infty)$ & 0.455 \\
\hline
\end{tabular}

$\mathrm{Cl}=$ confidence interval.

a Haplotypes deduced from informative combinations of genotypes. 
(rs1544410), Apal G>T (rs7975232), or Taql C > T (rs731236) SNPs of the VDR gene with type 1 diabetes mellitus in our population.

Such associations have been reported in populations from India [15], Taiwan [16], Germany [17-19], Hungary [14], Japan [20,21], the Netherlands [22], Croatia [23,24], Spain $[25,26]$, and Chile [27]. However, no associations were detected in other populations from Brazil [28], Romania $[29,30]$, Finland [30,31], Norway [30], the United States [30], and the United Kingdom [30].

The apparent discrepancies between this and other studies could be a result of the effect of ethnic differences related to the distribution of VDR polymorphisms in these populations, as well as to interactions with other genetic or environmental factors involved in the pathogenesis of type 1 diabetes mellitus. Human leukocyte antigen studies indicated that although the Portuguese are genetically related to Spaniards [32], they seem to have some ethnic-specific characteristics that distinguish them from other Europeans [32], and this may have contributed to the outcome of this study. Furthermore, because these polymorphisms, with the potential exception of the Fokl variant [33], have no known functional effects, the VDR itself may not be the diseaseaffecting locus, but rather a marker locus in linkage disequilibrium with the real disease locus, and the discrepant findings may reflect variable strengths of linkage disequilibrium in different populations.

In conclusion, our case-control study indicates that the four SNPs of the VDR gene studied are not associated with type 1 diabetes mellitus in the Portuguese population.

\section{Acknowledgment}

This work was supported, in part, by "Bolsa Dr. M. M. Almeida Ruas-Sociedade Portuguesa de Diabetologia/Novo Nordisk, em Diabetes (2003)."

\section{References}

[1] Nagpal S, Na S, Rathnachalam R. Noncalcemic actions of vitamin D receptor ligands. Endocr Rev 2005;26:662.

[2] Mathieu C, Waer M, Laureys J, Rutgeerts O, Bouillon R. Prevention of autoimmune diabetes in NOD mice by 1,25 dihydroxyvitamin D3. Diabetologia 1994;37:552.

[3] The EURODIAB Substudy 2 Study Group. Vitamin D supplement in early childhood and risk for Type I (insulin-dependent) diabetes mellitus. Diabetologia 1999;42:51.

[4] Hypponen E, Laara E, Reunanen A, Jarvelin MR, Virtanen SM. Intake of vitamin $D$ and risk of type 1 diabetes: a birth-cohort study. Lancet 2001;358:1500.

[5] Fronczak CM, Baron AE, Chase HP, et al. In utero dietary exposures and risk of islet autoimmunity in children. Diabetes Care 2003;26:3237.

[6] Crofts LA, Hancock MS, Morrison NA, Eisman JA. Multiple promoters direct the tissue-specific expression of novel $\mathrm{N}$-terminal variant human vitamin $D$ receptor gene transcripts. Proc Natl Acad Sci USA 1998;95:10529.

[7] Arai H, Miyamoto K, Taketani $Y$, et al. A vitamin D receptor gene polymorphism in the translation initiation codon: effect on protein activity and relation to bone mineral density in Japanese women. J Bone Miner Res 1997;12:915.
[8] Valdivielso JM, Fernandez E. Vitamin D receptor polymorphisms and diseases. Clin Chim Acta 2006;371:1.

[9] Lin WY, Wan L, Tsai CH, et al. Vitamin D receptor gene polymorphisms are associated with risk of Hashimoto's thyroiditis in Chinese patients in Taiwan. J Clin Lab Anal 2006; 20:109.

[10] Pani MA, Seissler J, Usadel KH, Badenhoop K. Vitamin D receptor genotype is associated with Addison's disease. Eur J Endocrinol 2002;147:635.

[11] Guo SW, Magnuson VL, Schiller JJ, et al. Meta-analysis of vitamin $D$ receptor polymorphisms and type 1 diabetes: a HuGE review of genetic association studies. Am J Epidemiol 2006; 164:711.

[12] World Health Organization. Definition, diagnosis and classification of diabetes mellitus and its complications: report of a WHO consultation. Geneva, World Health Organization, Department of Noncommunicable Disease Surveillance, 1999.

[13] Karvonen $M$, Viik-Kajander $M$, Moltchanova E, et al. Incidence of childhood type 1 diabetes worldwide. Diabetes Mondiale (DiaMond) Project Group. Diabetes Care 2000;23:1516.

[14] Gyorffy B, Vasarhelyi B, Krikovszky D, et al. Gender-specific association of vitamin $D$ receptor polymorphism combinations with type 1 diabetes mellitus. Eur J Endocrinol 2002;147:803.

[15] McDermott MF, Ramachandran A, Ogunkolade BW, et al. Allelic variation in the vitamin $D$ receptor influences susceptibility to IDDM in Indian Asians. Diabetologia 1997;40:971.

[16] Chang TJ, Lei HH, Yeh JI, et al. Vitamin D receptor gene polymorphisms influence susceptibility to type 1 diabetes mellitus in the Taiwanese population. Clin Endocrinol (Oxf) 2000;52:575.

[17] Pani MA, Knapp M, Donner $H$, et al. Vitamin D receptor allele combinations influence genetic susceptibility to type 1 diabetes in Germans. Diabetes 2000;49:504.

[18] Fassbender WJ, Goertz B, Weismuller K, et al. VDR gene polymorphisms are overrepresented in German patients with type 1 diabetes compared to healthy controls without effect on biochemical parameters of bone metabolism. Horm Metab Res 2002;34:330.

[19] Ramos-Lopez E, Jansen T, Ivaskevicius $V$, et al. Protection from type 1 diabetes by vitamin $D$ receptor haplotypes. Ann NY Acad Sci 2006;1079:327.

[20] Motohashi Y, Yamada S, Yanagawa T, et al. Vitamin D receptor gene polymorphism affects onset pattern of type 1 diabetes. J Clin Endocrinol Metab 2003;88:3137.

[21] Yokota I, Satomura S, Kitamura S, et al. Association between vitamin $D$ receptor genotype and age of onset in juvenile Japanese patients with type 1 diabetes. Diabetes Care 2002;25:1244.

[22] Koeleman BP, Valdigem G, Eerligh P, Giphart MJ, Roep BO. Seasonality of birth in patients with type 1 diabetes. Lancet 2002;359:1246; author reply 7 .

[23] Skrabic V, Zemunik T, Situm M, Terzic J. Vitamin D receptor polymorphism and susceptibility to type 1 diabetes in the Dalmatian population. Diabetes Res Clin Pract 2003;59:31.

[24] Zemunik T, Skrabic V, Boraska V, et al. Fokl polymorphism, vitamin $D$ receptor, and interleukin-1 receptor haplotypes are associated with type 1 diabetes in the Dalmatian population. J Mol Diagn 2005;7:600.

[25] Audi L, Marti G, Esteban C, et al. VDR gene polymorphism at exon 2 start codon (Fokl) may have influenced Type 1 diabetes mellitus susceptibility in two Spanish populations. Diabet Med 2004;21:393.

[26] San-Pedro JI, Bilbao JR, Perez de Nanclares G, et al. Heterogeneity of vitamin $D$ receptor gene association with celiac disease and type 1 diabetes mellitus. Autoimmunity 2005;38:439.

[27] Garcia D, Angel B, Carrasco E, et al. VDR polymorphisms influence the immune response in type 1 diabetic children from Santiago, Chile. Diabetes Res Clin Pract 2007;77:134. 
[28] Hauache OM, Lazaretti-Castro M, Andreoni S, et al. Vitamin D receptor gene polymorphism: correlation with bone mineral density in a Brazilian population with insulin-dependent diabetes mellitus. Osteoporos Int 1998;8:204.

[29] Guja C, Marshall S, Welsh K, et al. The study of CTLA-4 and vitamin $D$ receptor polymorphisms in the Romanian type 1 diabetes population. J Cell Mol Med 2002;6:75.

[30] Nejentsev S, Cooper JD, Godfrey L, et al. Analysis of the vitamin $D$ receptor gene sequence variants in type 1 diabetes. Diabetes 2004;53:2709.
[31] Turpeinen H, Hermann R, Vaara S, et al. Vitamin D receptor polymorphisms: no association with type 1 diabetes in the Finnish population. Eur J Endocrinol 2003;149:591.

[32] Arnaiz-Villena A, Martinez-Laso J, Gomez-Casado E, et al. Relatedness among Basques, Portuguese, Spaniards, and Algerians studied by HLA allelic frequencies and haplotypes. Immunogenetics 1997;47:37.

[33] van Etten E, Verlinden L, Giulietti A, et al. The vitamin D receptor gene Fokl polymorphism: functional impact on the immune system. Eur J Immunol 2007;37:395. 